\title{
IMMUNOHISTOCHEMICAL EVALUATION OF CARDIAC ANGIOGENESIS OF MICE EXPOSED TO SODIUM DICHROMATE AND LINDANE
}

\author{
BeKmuKhambetov, Y. - RAKHMANOV, S. - ZhANABAYEVA, A. ${ }^{*}$ \\ Marat Ospanov West-Kazakhstan State Medical University \\ 68 Maryes'yev Street, 030019 Aktobe, Kazakhstan \\ (phone: +7-713-256-3425; fax: +7-713-256-3201) \\ *Corresponding author \\ e-mail: aigulzhana@mail.ru; phone: +7-705-970-7755 \\ (Received 30 $0^{\text {th }}$ Jan 2019; accepted 28 ${ }^{\text {th }}$ Feb 2019)
}

\begin{abstract}
The immunohistochemical distribution and expression of the three markers in cardiomyocytes were evaluated in three groups of mice: a control group, mice exposed to $5 \mathrm{mg} / \mathrm{kg}$ b.w./day sodium dichromate (group A) and mice exposed to $100 \mathrm{mg} / \mathrm{kg} \mathrm{b.w./day} \mathrm{lindane} \mathrm{(group} \mathrm{B).} \mathrm{All} \mathrm{mice} \mathrm{were}$ sacrificed after 2 months of chronic exposure to the chemicals. Hematoxylin eosin staining revealed thickening of the anterior walls and thinning of the posterior walls of the left ventricle. Anterior and posterior vessel wall densities increased by a factor of about 1.5 in group A and about 2 in group B compared to the control group. Posterior wall vessel diameters declined by a factor of 3.7 in group A and 2.9 in group B. Immunohistochemical staining showed that sodium dichromate was associated with significantly lower expression of CD117 $(\mathrm{p}=0.019)$ and p53 $(\mathrm{p}=0.002)$ than in controls, whereas VEGF expression increased $(\mathrm{p}=0.03)$. In mice exposed to lindane, the results showed an opposite, though not significant trend, namely increased levels of CD117 and p53 and decreased levels of VEGF expression with respect to the control group. We observed significant changes in ventricular wall thickness, vessel density, vascular growth factor expression and mast cell apoptosis, directly correlated with exposure to lindane.
\end{abstract}

Keywords: $V E G F, C D 117, p-53$, aral sea area pollutants, chromium industry

\section{Introduction}

Among global environmental contaminants with pathogenic effects on the human body, those associated with the atmosphere, water, plants and soil are particularly prominent. Despite recent scientific and technological advances, the state of the environment continues to deteriorate year by year with negative impacts on human health.

Widespread use of chemical compounds in non-ferrous metallurgy and agriculture have increased the chemical burden of the human body. Chemicals including organochlorine pesticides are widely used to increase soil fertility, protect gardens and crops from insects, prevent infectious diseases and so forth. Chromium (VI) microelements and organochlorine pesticides, despite their different chemical nature, have toxic effects and trigger irreversible processes that affect organ histology. Structural changes in organs can lead to functional disorders in the same organs (Sánchez-Bayo et al., 2011; Cholewa et al., 2015).

The toxicity of hexavalent chromium and organochlorine pesticides has been shown to inhibit metabolic processes through genotoxic, embryotoxic, teratogenic and carcinogenic effects.

Sodium Dichromate is an orange to red colored, crystalline, inorganic compound that emits toxic chromium fumes upon heating. This chemical is used in drilling muds, in metal treatments, in wood preservatives, in the production of dyes and organic chemicals and as a corrosion inhibitor (PubChem, 2019a). 
Lindane is the gamma-isomer of benzene hexachloride, a colorless to white colored, synthetic, crystalline solid. It emits toxic fumes of hydrochloric acid and other chlorinated compounds when heated to decomposition. Lindane is used as an insecticide for hardwood logs, lumber, and crops (PubChem, 2019b).

Intensive production of various substances and products is accompanied by release of many residues, the harmful environmental effects of which have now reached a critical level. These residues may contain organochlorine compounds classified as persistent organic pollutants. Residues of pesticides and herbicides are particularly significant. Their toxicity to humans ranks them near the top in the hierarchy of global problems, while their intense and long-term effects lead to various diseases (Yunbo et al., 2016; Thompson et al., 2011; Yazicioglu et al., 2013; Seidler et al., 2013).

These substances have acute and chronic effects on human and animal health, depending on the type of pesticide, its route of intake, the dose, the moment and duration of exposure, the subject's age, gender and genotype, and geographic differences (Reid et al., 2013; Mehrpour et al., 2014).

The geographical location of our research team gives it a special interest in environmental health, since the Aktobe region includes part of the Aral Sea disaster area (Palmerini et al., 2017) and a chromite mining and smelting industry (Zhumalina et al., 2018). Environmental deterioration caused by Aral Sea disaster has created a hazardous situation for the health of approximately 3.5 million people. Due to this ecelogical circumstance, high levels of dichlorodiphenyltrichloroethane and other persistent organic pollutants appeared in the soil, air and water, as well as at every level of the food chain, including humans (Ataniyazova et al., 2001).

There is increasing evidence that exposure to these pollutants and chemicals can increase the risk of cardiovascular disease. Studies into the effects of pesticides on myocardial tissue reported cardiomyocyte decompensation, circulatory and lymph flow disturbances and changes in myofibrils (Stojanovic et al., 2016; Liu et al., 2017). In particular, complex irreversible processes in blood microcirculation and myocardial ultrastructure were found (Rückerl et al., 2007). Immunohistochemistry is an important tool in experimental research, in which monoclonal and polyclonal antibodies are applied to detect the distribution of an antigen in blood vessels and cardiac tissue (Duriyan et al., 2012).

Due to the high prevalence of cardiovascular disease in ecologically impaired regions, we focus here on the morphofunctional state of heart tissue. Our aim was to evaluate morphological changes in cardiac muscle tissue through an experiment involving chronic exposure of mice to sodium dichromate and lindane.

\section{Materials and methods}

\section{Ethics}

The design of the study was approved by the Local Ethical Commission of the Marat Ospanov West Kazakhstan State Medical University on 30th November 2015 (protocol no. 11) in line with the European Convention for the Protection of Vertebrates used for experimental and other purposes (Strasbourg, 1986).

\section{Exposure to sodium dichromate and lindane}

Sixty outbred white mice weighing 20-35 grams (females and males) (Laboratory of the Scientific and Practical Center of Marat Ospanov West-Kazakhstan State Medical 
University, Aktobe, Kazakhstan) were kept in the laboratory under a 12:12 h light-dark schedule (lights on 7 am to $7 \mathrm{pm}$ ) at $27^{\circ} \mathrm{C} \pm 2$ and $70 \%$ humidity with free access to unlimited water and food. The mice were divided into control (20) and experimental (40) groups. The experimental groups were divided into subgroups: group A: 20 mice exposed to $5 \mathrm{mg} / \mathrm{kg}$ b.w. per day sodium dichromate (Na2Cr2O7) (Rasool et al., 2014) (Sigma-Aldrich (MERCK, Darmstadt, Germany) and group B: 20 mice exposed to $100 \mathrm{mg} / \mathrm{kg}$ b.w. per day lindane (C6H6Cl6) (Vijaya Padma et al., 2013) (SigmaAldrich, MERCK, Darmstadt, Germany). The chemicals were administered orally through a smooth plastic tube attached to a syringe. The mice were sacrificed under ether anesthesia after 2 months of exposure to the chemicals.

\section{Histology and immunohistochemistry}

Paraffin embedded histological samples were fixed for hematoxylin eosin (HE) (Van Gieson) staining. Immunohistochemistry was conducted by a commercial laboratory subcontractor according to Thermo Fisher Scientific and Keele et al. (2008) protocols.

Three commercial monoclonal antibodies were used for immunohistochemical study: CD117/c-Kit/SCF-receptor rabbit monoclonal antibody, VEGF (SP28) rabbit monoclonal antibody and p53 monoclonal antibody (DO-7), all from Thermo Fisher Scientific.

To identify heart MCs, proto-oncogene c-Kit encoding a transmembrane tyrosine kinase receptor protein, c-Kit (CD117), is used. This antibody recognizes the extracellular domain and is expressed by a variety of normal and abnormal cell types, including cardiac MCs (Lammie et al., 1994).

VEGF expression levels are indeed directly correlated with endothelial status. This vascular layer contains a variety of receptors for interactions with bacteria, chemical particulate, vasoactive substances, hemostatic factors, immune factors, complement components and more (Berendt et al., 1989). The endothelium is therefore very sensitive and easily damaged.

Considering the importance of the above factors, we selected CD117 and p53 as markers to identify mast cells and apoptosis.

Another criterion for evaluating heart tissue ageing is the level of apoptosis. Apoptosis is a cell response to a wide range of toxic substances and leads to necrosis (Neuman et al., 2001, 2002). In vitro studies have proven that exposure to chemicals can induce oxidative stress and trigger apoptosis by activating apoptosis-initiator caspase-9 and apoptosis-effectors caspases-3 to 7 (Zerin et al., 2015). Since tumor suppressor Trp53 (p53) inhibits cell growth after acute stress by regulating gene transcription, it is an appropriate marker to study apoptosis in heart tissue (Mak et al., 2017).

Sections $3 \mu \mathrm{m}$ thick were applied to high-adhesive glass slides, treated with Lpolylysine and dried at room temperature for 24 hours. The staining was performed manually and using an AUTOSTAINER-360 (THERMO, UK) with NovoLinc polymer imaging systems ("NovoCastra", Great Britain). Controls for reaction sensitivity and specificity were unimmunized rabbit and mouse sera, and sections of control heart tissue.

Morphometric analysis of anterior and posterior walls of the left ventricle was performed with an Olympus model BX41 microscope at 40X magnification and "ImageJ" software. VEGF, CD117 on mast cells and apoptosis marker p53 were evaluated to determine toxic effects on heart tissue. Fluorescence microscopy was used 
to calculate the percentage of cells expressing VEGF, CD117 and p53 in representative frontal serial sections of the left ventricle. Cells were counted in three sections of similar sizes of the left ventricle of each mice heart.

\section{Statistical analysis}

The data was analyzed using the MedCalc software (MedCalc Software, Mariakerke, Belgium). The t-test was applied to the parameters of morphometric analysis. The Mann-Whitney test for independent samples was used to test for cell count differences in tissue sectionsbetween the control population and the population of exposed mice. Differences were considered statistically significant at $\mathrm{p}<0.05$.

\section{Results}

\section{Hematoxylin-eosin staining}

HE staining showed significantly higher thicknesses of the anterior left ventricular wall in experimental groups A and B than in the control group. Inversely, the posterior left ventricular wall was thinner (Fig. 1; Table 1). Vessel diameters were also significantly smaller. On the other hand, anterior and posterior wall densities increased in both experimental groups, reaching almost double the control density in group A ( $\mathrm{p}<0.0001$ ) (Table 1). Regarding the localization of vascularization, in the control group, vascular density was higher close to the epicardium, whereas in the experimental groups it was intense in the myocardium and endocardium. In group A, vessel walls were thinner and more compressed than in group B.

\section{Immunohistochemistry}

Expression of immunohistochemical markers varied in relation to chemical exposure. Results are summarized in Table 2.

Immunohistochemical staining showed that sodium dichromate significantly lowered expression of CD117 $(\mathrm{p}=0.019)$ and P53 $(\mathrm{p}=0.002)$ with respect to the control population and increased VEGF expression $(p=0.03)$. In mice exposed to lindane, the results showed the opposite sign, with non-significant increases in CD117 ( $p=0.08)$ and P53 expression $(\mathrm{p}=0.76)$ and a non-significant decrease in VEGF $(\mathrm{p}=0.62)$ with respect to the control group (Figs. 2 and 3).

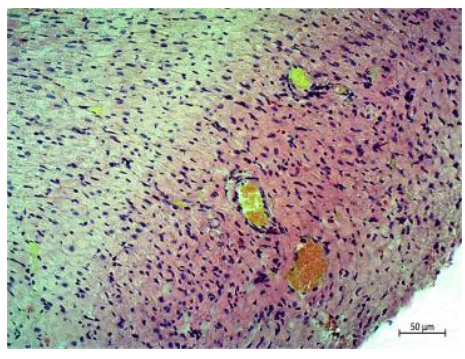

A

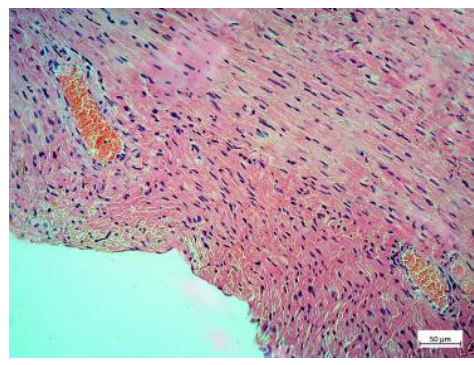

B

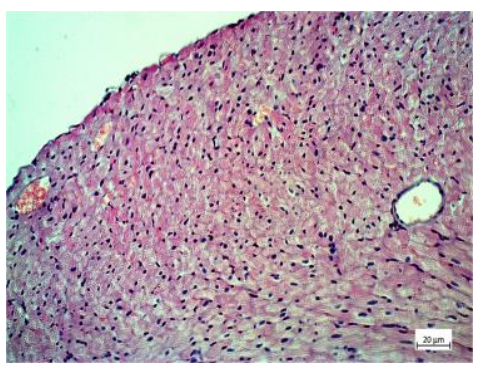

C

Figure 1. Structural changes in left ventricle wall. A. Control group. Vessel density, HE staining (x400). B. Group A. Vessel density. HE staining (x400). C. Group A. Vessel density. HE staining (x400) 


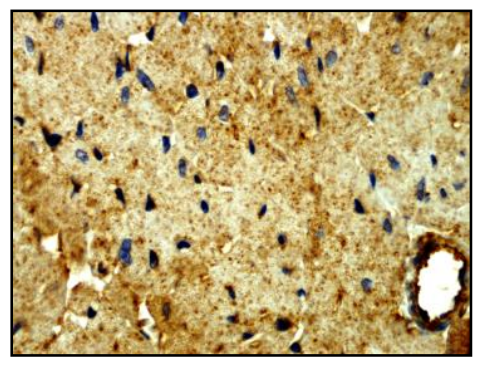

A

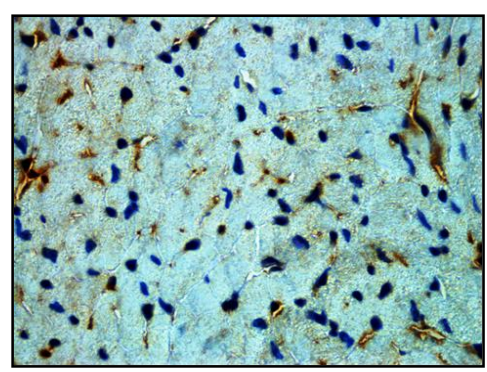

D

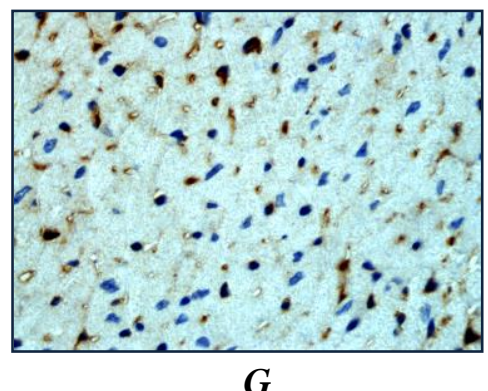

G

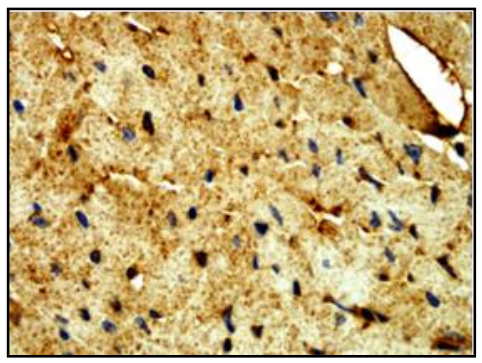

$\boldsymbol{B}$

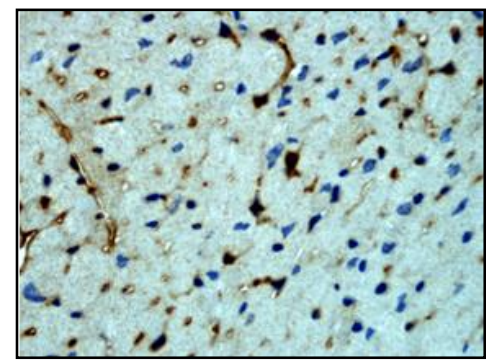

$\boldsymbol{E}$

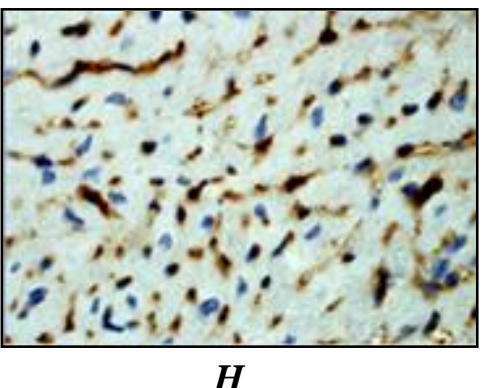

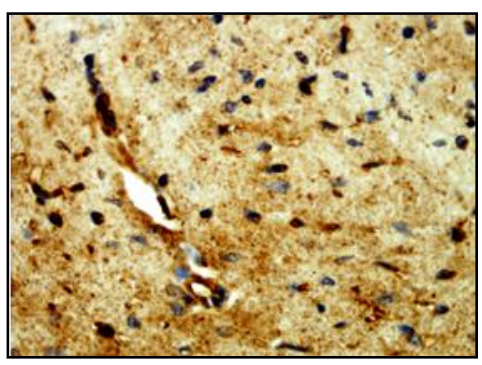

$C$
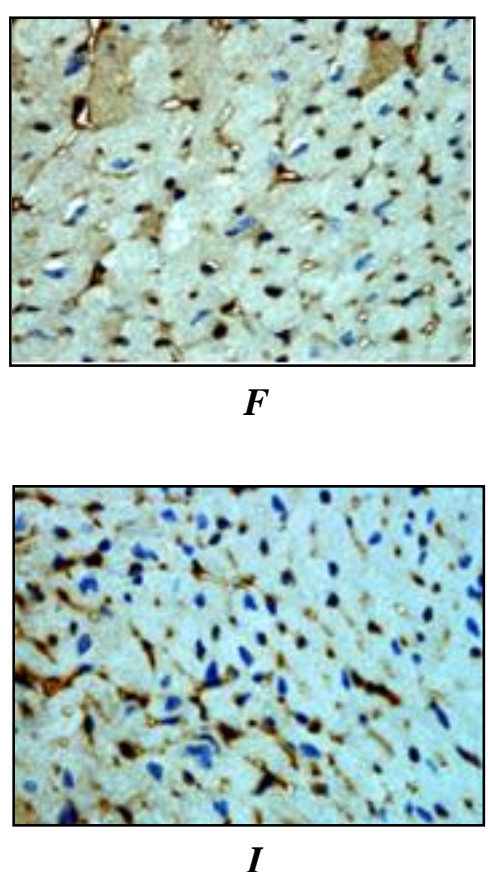

Figure 2. Immunohistochemical staining of left ventricle tissue. A. VEGF marker expression in Control group (x800). B. VEGF marker expression in group A (x800). C. VEGF marker expression in group $B(x 800)$. D. CD117 marker expression in Control group (x800). E.

$C D 117$ marker expression in group $A(x 800)$. F. CD117 marker expression in group $B(x 800)$. G. p53 marker expression in Control group. H. p53 marker expression in group A (x800). I. p53 marker expression in group $B(x 800)$

Table 1. Parameters of morphological changes in heart tissue

\begin{tabular}{c|c|c|c|c|c|c|c}
\hline \multicolumn{2}{c|}{ Parameters } & $\begin{array}{c}\text { Wall } \\
\text { thickness } \\
\text { (pixel) }\end{array}$ & t-test & $\begin{array}{c}\text { Vessel wall } \\
\text { density } \\
\text { (pixel) }\end{array}$ & t-test & $\begin{array}{c}\text { Vessel } \\
\text { diameters } \\
\text { (pixel) }\end{array}$ & t-test \\
\hline \multirow{4}{*}{$\begin{array}{c}\text { Anterior } \\
\text { wall }\end{array}$} & $\begin{array}{c}\text { Control } \\
\text { Group }\end{array}$ & $1186.1 \pm 0.02$ & & $8.2 \pm 0.1$ & & $727.14 \times 225.32$ & $\begin{array}{c}\text { Group A } \\
\text { Sodium } \\
\text { dichromate }\end{array}$ \\
\cline { 2 - 8 } & $1797.9 \pm 0.3$ & $\mathrm{p}<0.0001$ & $16.01 \pm 0.3$ & $\mathrm{p}<0.0001$ & $279.66 \times 102.18$ & $\mathrm{p}<0.0001$ \\
\hline $\begin{array}{c}\text { Group B } \\
\text { Lindane }\end{array}$ & $1550.24 \pm 0.3$ & $\mathrm{p}<0.0001$ & $11.6 \pm 0.02$ & $\mathrm{p}<0.0001$ & $256.04 \times 75.25$ & $\mathrm{p}<0.0001$ \\
\hline
\end{tabular}




\begin{tabular}{|c|c|c|c|c|c|c|c|}
\hline \multirow{3}{*}{$\begin{array}{c}\text { Posterior } \\
\text { wall }\end{array}$} & $\begin{array}{l}\text { Control } \\
\text { Group }\end{array}$ & $1359.39 \pm 0.05$ & & $6.1 \pm 0.04$ & & $910.8 \times 153.51$ & \\
\hline & $\begin{array}{c}\text { Group A } \\
\text { Sodium } \\
\text { dichromate }\end{array}$ & $1121.06 \pm 0.02$ & $\mathrm{p}<0.0001$ & $10.03 \pm 0.2$ & $\mathrm{p}<0.0001$ & $172.32 \times 66.87$ & $\mathrm{p}<0.0001$ \\
\hline & $\begin{array}{l}\text { Group B } \\
\text { Lindane }\end{array}$ & $996.76 \pm 0.01$ & $\mathrm{p}<0.0001$ & $8.3 \pm 0.4$ & $\mathrm{p}<0.0001$ & $219.81 \times 86.34$ & $\mathrm{p}<0.0001$ \\
\hline
\end{tabular}

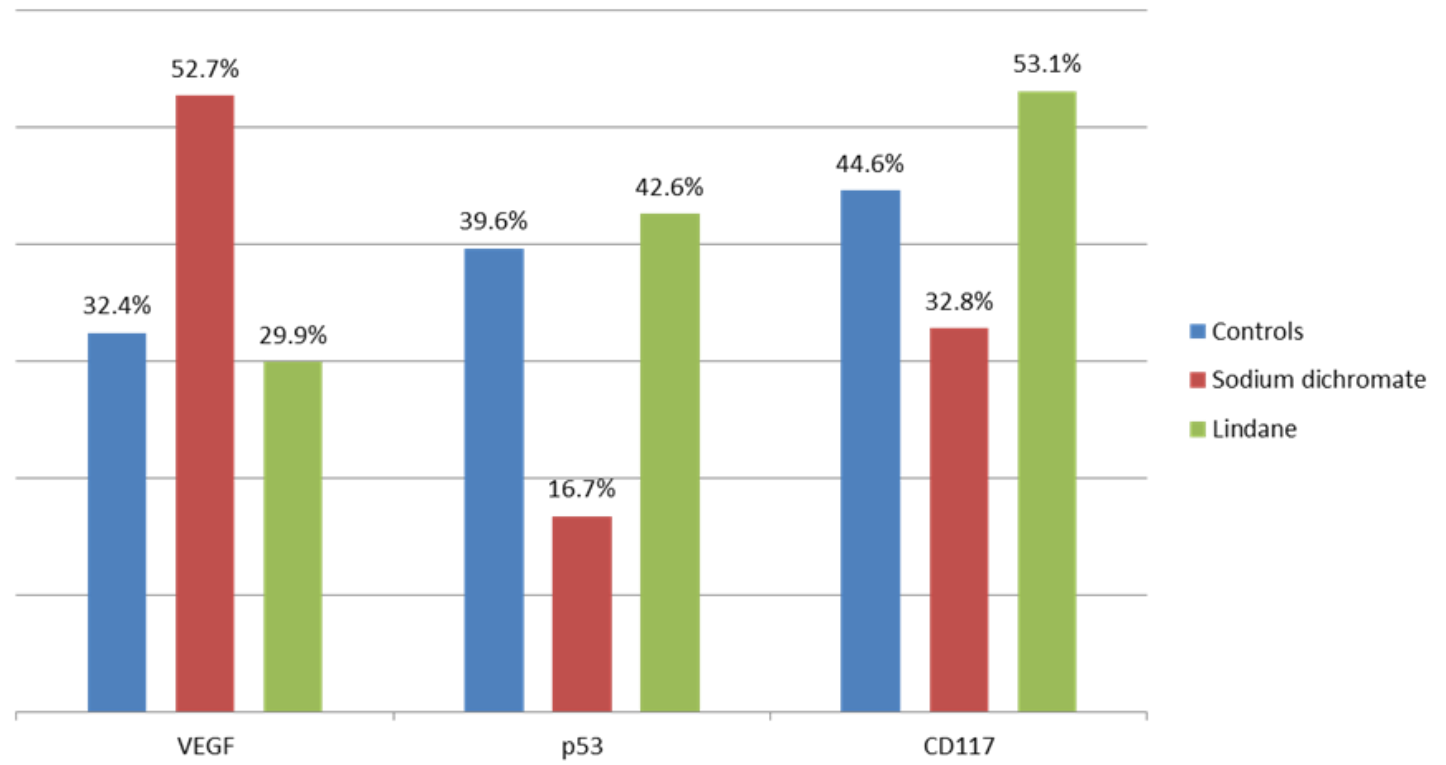

Figure 3. Histogram comparing expression of immunohistochemical markers in heart tissue of control and treated mice. Percentage of positivity in cells expressing VEGF, CD117 and p53, calculated as the sum of strongly and weakly antibody-positive cells in representative frontal serial sections of the left ventricle, showing that sodium dichromate significantly increased $V E G F$ levels in confront to the control population; on the contrary, lowered the expression of P53 and CD117. Immunohistochemical markers in mice exposed to lindane showed comparable results to the control group

Table 2. Immunohistochemical results with cell counts in mice

\begin{tabular}{c|c|c|c|c}
\hline \multirow{2}{*}{ Mice group/antibody } & \multicolumn{4}{|c}{ Percentage of positive cells } \\
\cline { 2 - 5 } & Strong & Weak & Total positive & Negative \\
\hline Controls/VEGF & $11.95 \pm 8.3$ & $20.48 \pm 10.1$ & $32.42 \pm 15.3$ & $67.10 \pm 15.3$ \\
Controls/p53 & $19.35 \pm 12.1$ & $20.28 \pm 10.6$ & $39.63 \pm 13.4$ & $60.37 \pm 13.4$ \\
Controls/CD117 & $10.35 \pm 3.9$ & $34.24 \pm 8.9$ & $44.59 \pm 9.9$ & $55.41 \pm 9.9$ \\
Sodium dicrhomate/VEGF & $18.39 \pm 11.7$ & $34.34 \pm 16.6$ & $52.72 \pm 18.6$ & $47.28 \pm 18.6$ \\
Sodium dicrhomate/p53 & $4.71 \pm 2.6$ & $12.03 \pm 4.4$ & $16.74 \pm 5.9$ & $83.26 \pm 5.9$ \\
Sodium dicrhomate/CD117 & $24.84 \pm 24.3$ & $7.98 \pm 5.0$ & $32.81 \pm 22.2$ & $67.19 \pm 22.2$ \\
Lindane/VEGF & $18.39 \pm 11.7$ & $34.34 \pm 16.6$ & $52.72 \pm 18.6$ & $47.28 \pm 18.6$ \\
Lindane/p53 & $20.73 \pm 9.1$ & $21.85 \pm 8.5$ & $42.58 \pm 11.8$ & $57.42 \pm 11.8$ \\
Lindane/CD117 & $16.50 \pm 6.1$ & $36.62 \pm 6.3$ & $53.12 \pm 11.1$ & $46.88 \pm 11.1$ \\
\hline
\end{tabular}




\section{Discussion}

A major criterion for evaluating aging processes is the biological age of blood vessels, in turn linked to the microstructural properties of the vascular wall. This is why it is important to study aging of heart vessels, i.e. the level of angiogenesis and apoptosis, particularly under conditions of exposure to chemicals (Saghiri et al., 2015; Haberzettl et al., 2012; Chin, 2015).

Researchers have confirmed that stress caused by exposure to chemicals and other factors predisposes to coronary heart disease and impairs heart function through stimulation of mast cells (MCs), leading to local inflammation (Alevizos et al., 2014). MCs contain mediators, such as cytokines, histamine, proteases and leukotrienes, and play an important role in inflammatory reactions, neovascularization and repair after myocardial injury (Galli and Wershil, 1995; Church and Levi-Schaffer, 1997; Welle, 1997; Hara et al., 1999; Zhang et al., 2006; Marone et al., 1995; Kennedy et al., 2005). Mast cell number and density are reported to be elevated in patients with cardiomyopathy (Patella et al., 1998). Acute stress of experimental myocardial infarction in rats was associated with increased MC density in affected areas during tissue remodelling. Researchers (Hara et al., 1999) reported that MCs caused apoptosis of cardiomyocytes and proliferation of non-myocardial cells, thus aggravating pathological heart conditions (Engels et al., 1995).

Chemical exposure causes pathological conditions in the vascular wall and affects vascular wall matrix remodeling.

CD117 plays an essential role, among others, in the regulation of cell survival and proliferation. Importantly, c-kit expression had been associated with heart repair after myocardial infarction (Cimini et al., 2007), where it establishes a proangiogenic milieu in the infarct border zone by increasing VEGF (Fazel et al., 2006).

The main distinguishing sign of endothelial aging is increasing vascular permeability, VEGF migration and reduction of regenerative capacity (Brandes et al., 2005). Our observation of increasing numbers of VEGF-expressing cells and their uneven concentrated distribution in the endothelium are polymorphic changes that indicate cell migration and damage to the vascular wall.

Gogiraju et al. revealed that p53-rich endothelial cells contribute to scarcity of blood vessels and development of fibrosis during cardiac hypertrophy and that apoptotic endothelial cell death plays an important role in chronic heart disease (Gogiraju et al., 2015). The present study showed that expression of CD117 and p53 decreased in the sodium dichromate experimental group with respect to controls, while VEGF expression is increased. It is known that lindane can cause abnormal heart rhythm (Sauviat and Pages, 2007) as well as histological alterations mainly in the left ventricular wall (Sauviat and Pages, 2002) and our morphological analyses confirms significant changes in heart tissue. However we did not observe any significant change in the three markers evaluated in the present study.

In healthy tissues, p53 function is inactive until induced by toxic or oncogenic stress (Sauviat and Pages, 2007). Biochemical stress activates beneficial gene sets, including proteins involved in excitation-contraction coupling, energy metabolism and response to oxidative stress through inhibition of hypertrophic signaling and apoptosis (Lammie et al., 1994). An increased rate of endothelial cell apoptosis reduces the regenerative capacity of the endothelium and leads to endothelial senescence (Barnabas et al., 2013). 
Chronic exposure to sodium dichromate and lindane modified the micro-structure of the left ventricle of the heart by increasing vessel wall density, narrowing the vessel lumen and increasing the number of small capillaries.

\section{Conclusions}

Exposure to lindane fosters aging processes in heart tissue due to an increase in the number of mast cells, which leads to apoptosis, cardiomyocyte necrosis and proliferation of non-myocardial tissue. Further research is needed to fully understand the effects of chronic exposure to chemicals and find out possible solutions for mitigating pollutants' effect by continuing experiment with protective pharmaceuticals against the risk of the occurance and progression of cardiovascular diseases. These prelimary findings justify the necessity of taking special preventive actions targeted to the zones exposed to chemical hazards.

Acknowledgements. We thank Professor Jürgen Hescheler, Dr. Marek Molcanyi and Mrs. Suzanne Wood of the Institute of Neurophysiology, University of Cologne, for their advice and for administration of the initial stage of the research, Dr. Matteo Bertelli Dr. Paolo Enrico Maltese and Dr. Yeltay Rakhmanov from MAGI, International Institute for Diagnostics and Research of Genetic and Rare Diseases, Rovereto, Italy for their help in writing this article, commercial laboratory subcontractor “Avizzena Medical Center", Novosibirsk, Russian Federation, for providing laboratory facilities, and Helen Ampt for revising the English.

\section{REFERENCES}

[1] Alevizos, M., Karagkouni, A, Panagiotidou, S., Vasiadi, M., Theoharides, T. C. (2014): Stress triggers coronary mast cells leading to cardiac events. - Annals of Allergy, Asthma and Immunology 112(4): 309-16.

[2] Ataniyazova, O. A., Baumann, R. A., Liem, A. K., Mukhopadhyay, U. A., Vogelaar, E. F., Boersma, E. R. (2001): Levels of certain metals, organochlorine pesticides and dioxins in cord blood, maternal blood, human milk and some commonly used nutrients in the surroundings of the Aral Sea (Karakalpakstan, Republic of Uzbekistan). - Acta Paediatr. 90(7): 801-8.

[3] Barnabas, O., Wang, H., Gao, X. M. (2013): Role of estrogen in angiogenesis in cardiovascular diseases. - Journal of Geriatric Cardiology 10(4): 377-82.

[4] Berendt, A. R., Simmons, D. L., Tansey, J., Newbold, C. I., Marsh, K. (1989): Intercellular adhesion molecule-1 is an endothelial cell adhesion receptor for Plasmodium falciparum. - Nature 341(6237): 57-9.

[5] Brandes, R. P., Fleming, I., Busse, R. (2005): Endothelial aging. - Cardiovascular Research 66(2): 286-94.

[6] Chin, M. T. (2015): Basic mechanisms for adverse cardiovascular events associated with air pollution. - Heart 101(4): 253-6.

[7] Cholewa, R., Beutling, D., Budzyk, J., Pietrzak, M., Walorczyk, S. (2015): Persistent organochlorine pesticides in internal organs of coypu, Myocastor coypus. - Journal of Environmental Science and Health 50/8: 590-594.

[8] Church, M. K., Levi-Schaffer, F. (1997): The human mast cell. - Journal of Allergy and Clinical Immunology 99: 155-160.

[9] Cimini, M., Fazel, S., Zhuo, S., Xaymardan, M., Fujii, H., Weisel, R. D., Li, R. K. (2007): c-kit dysfunction impairs myocardial healing after infarction. - Circulation 116(11 Suppl): I77-82. 
[10] Duraiyan, J., Govindarajan, R., Kaliyappan, K., Palanisamy, M. (2012): Applications of immunohistochemistry. - Journal of Pharmacy \& Bioallied Sciences 4(Suppl 2): S307-9.

[11] Engels, W., Reiters, P. H., Daemen, M. J., Smits, J. F., van der Vusse, G. J. (1995): Transmural changes in mast cell density in rat heart after infarct induction in vivo. Journal of Pathology 177: 423-429.

[12] Fazel, S., Cimini, M., Chen, L., Li, S., Angoulvant, D., Fedak, P., Verma, S., Weisel, R. D., Keating, A., Li, R. K. (2006): Cardioprotective c-kit+ cells are from the bone marrow and regulate the myocardial balance of angiogenic cytokines. - Journal of Clinical Investigation 116(7): 1865-77.

[13] Galli, S. J., Wershil, B. K. (1995): Mouse mast cell cytokine production: role in cutaneous inflammatory and immunological responses. - Experimental Dermatology 4: 240-249.

[14] Gogiraju, R., Xu, X., Bochenek, M. L., Steinbrecher, J. H., Lehnart, S. E., Wenzel, P., Kessel, M., Zeisberg, E. M., Dobbelstein, M., Schafer, K. (2015): Endothelial p53 deletion improves angiogenesis and prevents cardiac fibrosis and heart failure induced by pressure overload in mice. - Journal of American Heart Association 4(2).

[15] Haberzettl, P., Lee, J., Duggineni, D., McCracken, J., Bolanowski, D., O’Toole, T. E., Bhatnagar, A., Conclin, D. J. (2012): Exposure to ambient air fine particulate matter prevents VEGF-induced mobilization of endothelial progenitor cells from the bone marrow. - Environmental Health Perspectives 120(6): 848-56.

[16] Hara, M., Matsumori, A., Ono, K., Kido, H., Hwang, M. W., Miyamoto, T., Iwasaki, M., Okada, M., Nakatani, K., Sasayama, S. (1999): Mast cells cause apoptosis of cardiomyocytes and proliferation of other intramyocardial cells in vitro. - Circulation 100(13): 1443-9.

[17] Keele, J. A., Mark, M., Stayton, M. M. (2008): Immunohistochemistry in the Heart: A Protocol Manual. - Department of Molecular Biology, University of Wyoming, Laramie, WY. https://www.uwyo.edu/molecbio/faculty-and-staff/mark-stayton/_files/ihc-heartprotocols.pdf.

[18] Kennedy, R. H., Hauer-Jensen, M., Joseph, J. (2005): Cardiac function in hearts isolated from a rat model deficient in mast cell. - American Journal of Physiology - Heart and Circulatory Physiology 288: H632-637.

[19] Lammie, A., Dobnojak, M., Gerald, W., Saad, A., Cote, R., Cordon-Cardo, C. (1994): Expression of c-Kit and Kit ligand proteins in normal human tissues. - Journal of Histochemistry and Cytochemistry 42: 1417-1425.

[20] Liu, N., Shi, Y., Diao, H., Li, Y. (2017): MicroRNA-135a Regulates apoptosis induced by hydrogen peroxide in rat cardiomyoblast cells. - International Journal of Biological Sciences 13; 1: 13-21.

[21] Mak, T. W., Hauck, L., Grothe, D., Billia, F. (2017): p53 regulates the cardiac transcriptome. - Proceedings of the National Academy of Sciences of the United States of America 114(9): 2331-2336.

[22] Marone, G., de Crescenzo, G., Adt, M., Patella, V., Arbustini, E., Genovese, A. (1995): Immunological characterization and functional importance of human heart mast cells. Immunopharmacology 31: 1-18.

[23] Mehrpour, O., Karrari, P., Zamani, N., Tsatsakis, A. M., Abdollahi, M. (2014): Occupational exposure to pesticides and consequences on male semen and fertility: a review. - Toxicol Letter 230(2): 146-56.

[24] Neuman, M. G. (2002); Apoptosis in liver disease. - Romanian Journal of Gastroenterology 11: 3-7.

[25] Neuman, M. G., Katz, G. G., Malkiewicz, I. M. Mathurin, P., Tsukamoto, H., Adachi, M., Ishii, H., Colell, A., Carcia-Ruiz, C., Fernandez-Checa, J. C., Casey, C. A. (2001): Alcoholic liver injury and apoptosis-synopsis of the symposium held at ESBRA. Alcohol 28: 117-28. 
[26] Palmerini, M. G., Zhurabekova, G., Balmagambetova, A., Nottola, S. A., Miglietta, S., Belli, M., Bianchi, S., Cecconi, S., Di Nisio, V., Familiari, G., Macchiarelli, G. (2017): The pesticide Lindane induces dose-dependent damage to granulosa cells in an in vitro culture. - Reproductive Biolology 17(4): 349-356.

[27] Patella, V., Marino. I., Arbustini, E., Lampater-Schummert, B., Verga, L., Adt, M., Marone, G. (1998): Stem cell factor in mast cells and increased mast cell density in idiopathic and ischemic cardiomyopathy. - Circulation 97: 971-978.

[28] PubChem (2019a): National Center for Biotechnology Information. PubChem Compound Database; CID=25408. - https://pubchem.ncbi.nlm.nih.gov/compound/25408 (accessed Feb. 19, 2019).

[29] PubChem (2019b): National Center for Biotechnology Information. PubChem Compound Database; CID=727. - https://pubchem.ncbi.nlm.nih.gov/compound/727 (accessed Feb. 19, 2019).

[30] Rasool, M., Zaigham, K., Malik, A., Naseer, M. I., Umm-E-Habiba, Manan, A., Qazi, M. H., Asif, M. (2014): Potential reproductive health effects and oxidative stress associated with exposure to potassium dichromate (K2Cr2O7) and magnesium sulphate (MgSO4) in male mice. - Pakistan Journal of Medical Sciences 30(4): 819-23.

[31] Reid, A., Callan, A., Stasinska, A., Heyworth, J., Phi, D. T., Odland, J. O., Hinwood, A. (2013): Maternal exposure to organochlorine pesticides in Western Australia. - Science of the Total Environment 449: 208-13.

[32] Rückerl, R., Greven, S., Ljungman, P., Aalto, P., Antoniades, C., Bellander, T., Rückerl, R., Greven, S., Ljungman, P., Aalto, P., Antoniades, C., Bellander, T., Berglind, N., Chrysohoou, C., Forastiere, F., Jacquemin, B., von Klot, S., Koenig, W., Küchenhoff, H., Lanki, T., Pekkanen, J., Perucci, C. A., Schneider, A., Sunyer, J., Peters, A., AIRGENE Study Group (2007): Air pollution and inflammation (interleukin-6, C-reactive protein, fibrinogen) in myocardial infarction survivors. - Environmental Health Perspectives 115(7): 1072-80.

[33] Saghiri, M. A., Asatourian, A., Orangi, J., Sorenson, C. M., Sheibani, N. (2015): Functional role of inorganic trace elements in angiogenesis, Part I: N, Fe, Se, P, Au, and Ca. - Critical Review of Oncology and Hematology 96(1): 129-42.

[34] Sauviat, M. P., Pages, N. (2002): Cardiotoxicity of lindane, a gamma isomer of hexachlorocyclohexane. - Journal de la Société de Biologie 196(4): 339-48.

[35] Sauviat, M. P., Pagès, N. (2007): Effects of lindane (gamma-hexachlorocyclohexane) on rat heart muscle contraction. - General Physiology and Biophysics 26(4): 275-80.

[36] Sánchez-Bayo, F., van den Brink, P. J., Mann, R. M. (2011): Impacts of agricultural pesticides on terrestrial ecosystems. - Ecological Impacts of Toxic Chemicals 2011: 6387.

[37] Seidler, A., Jahnichen, S., Hegewald, J., Fishta, A., Krug, O., Ruter, L., Strik, C., Hallier, E., Straube, S. (2013): Systematic review and quantification of respiratory cancer risk for occupational exposure to hexavalent chromium. - International Archivium of Occupational and Environmental Health 86: 943-955.

[38] Stojanovic, M., Zivkovic, V., Srejovic, I., Jakovljevic, V., Jeremic, N., Djuric, D. (2016): The role of hydrogen sulfide in homocysteine-induced cardiodynamic effects and oxidative stress markers in the isolated rat heart. - Physiology International 103(4): 428438.

[39] Thermo Fisher Scientific. Immunohistochemistry Protocol (Paraffin) for Application Testing. - https://www.thermofisher.com/it/en/home/life-science/antibodies/antibodieslearning-center/antibodies-resource-library/antibody-application-testingprotocols/immunohistochemistry-paraffin-protocol-application-testing.html.

[40] Thompson, C. M., Proctor, D. M., Haws, L. C., Hébert, C. D., Grimes, S. D., Shertzer, H. G., Kopec, A. K., Hixon, J. G., Zacharewski, T. R., Harris, M. A. (2011): Investigation of the mode of action underlying the tumorigenic response induced in $\mathrm{B} 6 \mathrm{C} 3 \mathrm{~F} 1$ mice exposed orally to hexavalent chromium. - Toxicological Sciences 123(1): 58-70. 
[41] Vijaya Padma, V., Poornima, P., Prakash, C., Bhavani, R. (2013): Oral treatment with gallic acid and quercetin alleviates lindane-induced cardiotoxicity in rats. - Canadian Journal of Physiology and Pharmacology 91(2): 134-40.

[42] Welle, M. (1997): Development, significance, and heterogeneity of mast cells with particular regard to the mast cell-specific proteases chymase and tryptase. - Journal of Leukocyte Biology 61: 233-245.

[43] Yazicioglu, S., Bankaoglu, G., Aydemir, O. (2013): Toxic effects of pesticides to humans and environment. - Geoconference on Ecology, Economics, Education and Legislation, Sgem, 2013, Vol. 1, pp. 1107-1112.

[44] Yunbo, Zh., Jipeng, G., Xiao, Z., Jingjing, G., Ming, Z., Yang, Y. (2016): Interaction effects between organochlorine pesticides and isoflavones in vitro and in vivo. - BioMed Research International 6861702: 1-7.

[45] Zerin, T., Kim, J. S., Gil, H. W., Song, H. Y., Hong, S. Y. (2015): Effects of formaldehyde on mitochondrial dysfunction and apoptosis in SKN-SH neuroblastoma cells. - Cell Biology and Toxicology 31: 261-72.

[46] Zhang, Q. Y., Ge, J. B., Chen, J. Z., Zhu, J. H., Zhang, L. H., Lau, C. P., Tse, H. F. (2006): Mast cell contributes to cardiomyocyte apoptosis after coronary microembolization. - Journal of Histochemistry and Cytochemistry 54(5): 515-23.

[47] Zhumalina, A. K., Bekmukhambetov, E. Z., Tusupkaliev, B. T., Zharlikasinova, M. B. (2018): Development of scientifically justified proposals on the prevention and treatment of environmentally determined constitutional growth delay in children in the West Kazakhstan region. - Environmental Geochemistry and Health. DOI: 10.1007/s10653018-0210-0. 